\title{
PERAN ENGAGING LEADERSHIP TERHADAP KOMITMEN ORGANISASIONAL DALAM PROXIMAL WITHDRAWAL STATES
}

\author{
Maria Regina Tinon Dyah Kentami ${ }^{1}$, Rostiana $^{2}$ \\ ${ }^{1}$ Program Studi Magister Psikologi, Universitas Tarumanagara, Jakarta \\ Email: Maria.717181023@stu.untar.ac.id \\ ${ }^{2}$ Fakultas Psikologi, Universitas Tarumanagara, Jakarta \\ Email: rostiana@fpsi.untar.ac.id
}

Masuk : 01-05-2020, revisi: 27-10-2020, diterima untuk diterbitkan : 31-10-2020

\begin{abstract}
Preserving competent employees is still a primary challenge for the organization today. Every company needs to make efforts to retain the employees they have. PT.X is one of the companies operating in the education sector that needs to anticipate future turnovers. This study aims to investigate the role of engaging leadership toward organizational commitment in the Proximal Withdrawal States (PWS) at PT. X. Researchers hope that by great engaging leadership, the organizational commitment will improve so that the probability of turnover will decrease. The study was administered on 295 employees at PT. X, who is a permanent employee and had worked for more than one year. This research belongs to non-experimental quantitative research. A simple regression model was conducted to process the data of this study. The results showed that engaging leadership had a significant role of $16.8 \%$ toward organizational commitment. However, based on the situation description, engaging leadership only plays a significant role in the "reluctant stayers," "reluctant leavers," and "enthusiastic stayers" situation. In the "reluctant stayers" situation, engaging leadership accounts for 12.1\%. In the "reluctant leavers" situation, a significant role of $62.7 \%$ was found, and $8.4 \%$ in the "enthusiastic stayers" situation. Furthermore, it is revealed that engaging leadership only plays a significant role toward the continual and normative commitment dimensions in the "reluctant stayers" situation. Meanwhile, in the "reluctant leavers" and "enthusiastic stayers" situation, engaging leadership only plays a significant role in the affective and normative commitment dimensions.
\end{abstract}

Keywords: engaging leadership, turnover, organisasional commitment, proximal withdrawal states

\begin{abstract}
ABSTRAK
Memperoleh karyawan yang kompeten saat ini masih menjadi tantangan utama bagi organisasi. Setiap perusahaan perlu melakukan upaya untuk mempertahankan karyawan yang dimilikinya saat ini. PT. X menjadi salah satu perusahaan yang bergerak di bidang Pendidikan yang perlu melakukan antisipasi terjadinya turnover di masa depan. Penelitian ini bertujuan untuk melihat peran engaging leadership terhadap komitmen organisasi dalam situasi Proximal Withdrawal States (PWS) pada PT. X. Peneliti berharap dengan engaging leadership yang baik, maka komitmen organisasi akan meningkat sehingga peluang terjadinya turnover akan munurun. Penelitian dilakukan pada 295 karyawan yang bekerja di PT. X dengan kriteria sebagai pegawai tetap dan sudah bekerja lebih dari satu tahun. Penelitian ini termasuk ke dalam penelitian kuantitatif non eksperimental. Pengolahan data dilakukan dengan model regresi sederhana. Hasil penelitian menunjukan bahwa engaging leadership berperan signifikan sebesar $16,8 \%$ terhadap komitmen organisasi. Namun pada gambaran situasi, engaging leadership hanya berperan signifikan pada situasi reluctan stayers, reluctant leavers dan enthusiastic stayers. Pada situasi reluctant stayers, engaging leadership berperan sebesar $12,1 \%$. Pada situasi reluctant leavers berperan signifikan sebesar $62,7 \%$ dan $8,4 \%$ pada situasi enthusiastic stayers. Lebih detil lagi dijabarkan bahwa engaging leadership hanya berperan signifikan terhadap dimensi komitmen kontinual dan normatif dalam situasi reluctant stayers. Sementara itu pada situasi reluctant leavers dan enthusiastic stayers, engaging leadership hanya berperan signifikan pada dimensi komitmen afektif dan normatif.
\end{abstract}

Kata Kunci: engaging leadership, turnover, komitmen organisasional, proximal withdrawal states

\section{PENDAHULUAN Latar Belakang}

Tantangan yang menghambat pertumbuhan organisasi saat ini adalah sulitnya memperoleh karyawan yang kompeten, inovasi proses bisnis berkelanjutan dan pengembangan kemampuan karyawan dalam menghadapi perubahan yang terjadi terus menerus (Pekasa, \& Rostiana, 2018). 
Hal itu dinyatakan melalui survei yang dilakukan KPMG International (lembaga jasa professional) terhadap 1300 CEO pada 11 sektor industri dari 11 negara dengan ekonomi terkuat. Memperoleh karyawan yang kompeten saat ini masih menjadi tantangan utama bagi organisasi, sehingga perusahaan perlu mempertahankan karyawan yang dimilikinya saat ini. Kehilangan karyawan yang kompeten merupakan kerugian besar bagi organisasi. Hal ini dapat dilihat melalui beberapa biaya yang akan dikeluarkan organisasi sebagai akibat dari adanya karyawan yang keluar dari organisasi. Biaya tersebut meliputi biaya untuk penca rian dan penerimaan karyawan baru, biaya pelatihan bagi karyawan baru serta biaya-biaya lain yang mungkin dikeluarkan selama karyawan baru melakukan adaptasi dengan pekerjaan barunya. Berdasarkan hal tersebut, maka dapat dikatakan organisasi kehilangan aset atau sumber daya yang telah diinvestasikan pada karyawan. Oleh karna itu resiko kehilangan karyawan pada organisasi perlu diantisipasi.

Dalam upaya menghindari kerugian yang telah dijabarkan diatas, peneliti melakukan pengambilan data terkait Proximal Withdrawal State (PWS) pada PT. X Jakarta. Hom et al. (2012) memperkenalkan PWS sebagai perluasan dari kriteria turnover yang melihat dua antesenden utama dan terdekat dengan turnover, yaitu preferensi untuk keluar atau menetap dalam organisasi (leaving atau staying) dan perceived control over preference (enthusiastic atau reluctant). Berdasarkan kedua hal tersebut PWS dibagi menjadi empat jenis, yaitu enthusiastic leavers (preferensi yang tinggi untuk keluar dan kontrol yang tinggi terhadap preferensi tersebut), enthusiastic stayers (preferensi yang tinggi untuk menetap dan kontrol yang tinggi terhadap preferensi tersebut), reluctant leavers (preferensi yang tinggi untuk menetap dan kontrol yang rendah terhadap preferensi tersebut) dan reluctant stayers (preferensi yang tinggi untuk keluar dan kontrol yang rendah terhadap preferensi tersebut) (Hom et al., 2012). Melalui PWS, Hom et al. (2012) memprediksi turnover dalam organisasi secara lebih terperinci.

Untuk menghindari kerugian dengan terjadinya turnover, peneliti melakukan pengambilan data awal yang dilakukan pada 36 karyawan yang bekerja di PT. X dengan menyebarkan kuisioner terkait situasi PWS yang dirasakan karyawan terhadap organisasi saat ini. Hasil survei menunjukan bahwa 11\% karyawan berada pada situasi enthusiastic leaver, 41,6\% karyawan berada pada situasi reluctant stayer, 13,8\% karyawan berada pada situasi reluctant leaver dan $33 \%$ karyawan berada pada situasi enthusiastic stayer.

Meskipun tingkat turnover di PT. X tergolong rendah dimana pada tahun 2018 tercatat sebesar $7 \%$, hal ini tidak menutup kemungkinan PT. X tidak memiliki resiko kehilangan karyawan. Hasil pengambilan data mencatat $41,6 \%$ karyawan berada pada situasi reluctant stayers, dimana karyawan pada kondisi ini merupakan karyawan yang memiliki preferensi tinggi untuk keluar namun memiliki kontrol yang rendah terhadap preferensi tersebut. Selain itu hasil pengambilan data juga menunjukan terdapat $11 \%$ karyawan yang berada pada situasi enthusiastic leavers. Hal tersebut menggambarkan bahwa PT. X akan segera kehilangan beberapa karyawannya dalam waktu dekat. Peneliti selanjutnya melakukan wawancara untuk memperoleh data yang lebih detil terkait dengan kondisi karyawan PT. X saat ini. Hasil wawancara menunjukan bahwa karyawan yang berada pada situasi enthusiastic leavers dan reluctant stayers memiliki komitmen organisasi yang rendah. Hasil wawancara ini juga di dukung oleh penelitian Li et al. (2016) yang menyatkan bahwa karyawan dengan reluctant stayers dan enthusiastic leavers memiliki komitmen yang rendah.

Hingga saat ini belum ada penelitian yang mengambarkan bentuk tiga komponen komitmen dalam reluctant stayers secara terpisah. Namun berdasarkan kondisi reluctant stayers dimana 
mereka memiliki preferensi untuk keluar namun tidak dapat melakukannya dikarnakan pertimbangan akan beberapa hal yang dapat merugikannya, maka dapat dilihat bahwa komitmen yang menyebabkan mereka masih menetap hingga saat ini adalah komitmen kontinual. Hal tersebut juga memperlihatkan bahwa reluctant stayers memiliki komitmen afektif dan normatif yang rendah. Efek dari komitmen kontinual yang tinggi adalah ketika karyawan berhasil memiliki kontrol terhadap preferensinya untuk keluar, maka resiko PT.X kehilangan karyawannya dapat terjadi. Seperti yang terjadi pada enthusiastic leaver. Enthusiastic leaver juga memiliki komitmen yang rendah (Li et al., 2016), yang apabila dilihat dari kondisinya dengan preferensi untuk keluar dan memiliki control yang besar akan hal tersebut, maka dapat dinyatakan bahwa enthusiastic leaver memiliki komitmen afektif, kontinual dan normatif yang rendah.

Hasil pengambilan data selanjutnya menunjukan bahwa PT.X memiliki 33\% karyawan yang berada pada enthusiastic stayers. Karyawan pada enthusiastic stayers memiliki kepuasan, komitmen dan keterlibatan kerja yang tinggi pada organisasi (Li et al., 2016). Dan yang terakhir adalah situasi reluctant leavers. Reluctant leavers yang terdapat pada PT.X berdasarkan hasil perolehan data adalah sebesar $13,8 \%$. Karyawan dengan reluctant leavers memiliki preferensi untuk menetap tetapi tidak memiliki kontrol atas preferensi tersebut.

Hasil kualitatif pengukuran PWS pada PT. X juga menunjukan tidak terpenuhinya kebutuhan dasar karyawan dari atasan dalam organisasi pada situasi enthusiastic leavers dan reluctant leavers. Melihat hal tersebut maka dapat dilihat bahwa karyawan dengan komitmen organisasi yang rendah, juga merasa tidak terpenuhi kebutuhan dasar dalam organisasi melalui atasan. Untuk mengatasi hal tersebut, Schaufeli (2015) memperkenalkan sebuah konsep kepemimpinan yang berkaitan dengan pemenuhan kebutuhan dasar karyawan yang disebut dengan engaging leadership. Engaging leadership mampu memenuhi kebutuhan dasar karyawan dengan memberdayakan, menginspirasi, menguatkan dan menghubungkan karyawan (Rahmadani et al., 2019).

Penelitian yang dilakukan Schaufeli (2015) terkait engaging leadership menunjukan hasil bahwa engaging leadership memiliki pengaruh yang positif terhadap komitmen organisasional secara langsung. Namun dalam penelitian ini belum digambarkan dengan jelas komponen komitmen mana yang akan meningkat dengan adanya peran engaging leader di dalamnya. Melihat kerugian-kerugian yang mungkin saja dialami PT.X kedepan dikarnakan sikap kerja yang diberikan reluctant stayers dan enthuestic leavers serta kemungkinan karyawan meninggalkan organisasi yang cukup besar, peneliti kemudian tertarik untuk melihat kembali peranan engaging leader terhadap komitmen organisasional dalam kondisi PWS. Peneliti ingin melihat secara lebih detil peran engaging leader terhadap satu persatu komponen komitmen organisasional.

Dengan adanya penelitian ini penelitini berharap komponen-komponen komitmen organisasional yang dimiliki karyawan dalam 4 situasi PWS dapat meningkat dengan dengan adanya engaging leadership, sehingga resiko PT.X kehilangan karyawannya dapat menurun. Penelitian ini akan dilakukan pada karyawan PT.X Jakarta yang merupakan karyawan tetap dan memiliki masa bekerja lebih dari 1 tahun. Pemilihan subjek penelitian didasarkan pada rata-rata usia karyawan yang berada di PT.X Jakarta. Berdasarkan latar belakang dan identifikasi masalah, pertanyaan yang akan dijawab melalui penelitian ini adalah: Apakah terdapat peran engaging leadership terhadap komitmen organisasi dalam situasi Proximal Withdrawal States?. 


\section{METODE PENELITIAN}

\section{Partisipan}

Karyawan PT. X sebagai populasi dalam penelitian ini berjumlah 1.109 orang. Penelitian ini dilakukan pada karyawan tetap PT. X Jakarta yang berada pada posisi staff hingga tingkat managerial. Usia partisipan dalam penelitian ini tidak dibatasi untuk melihat gambaran responden secara luas. Karyawan yang dapat mengikuti penelitian adalah karyawan yang memiliki masa kerja minimal satu tahun serta memiliki status kepegawaian sebagai karyawan tetap. Pada rencana pengambilan data, peneliti telah membagi sampel ke dalam setiap populasi yang ada serta menyebarkan kuisioner penelitian kepada 308 partisipan. Setelah proses penyebaran data selesai, peneliti melakukan pemeriksaan data kembali dan menemukan bahwa hanya 295 data yang dapat diolah untuk penelitian. Berdasarkan rumus Slovin data tersebut sudah cukup representative untuk mewakili populasi yang ada.

\section{Desain Penelitian}

Teknik pengambilan sampel yang digunakan dalam penelitian ini adalah disproportionate stratified random sampling. Dalam metode disproportionate stratified random sampling, peneliti mengelompokkan calon responden penelitian berdasarkan kriteria-kriteria tertentu kemudian mereka dipilih secara acak untuk menjadi responden (Kumar, 2005). Peneliti membagi responden ke dalam kelompok-kelompok divisi yang memiliki jumlah populasi yang berbeda.

Penelitian ini termasuk ke dalam penelitian non ekperimental karena penelitian ini dilakukan terhadap sejumlah subjek penelitian menurut keadaan apa adanya, tanpa ada manipulasi atau intervensi peneliti (Neuman, 2014). Metode pendekatan yang digunakan dalam penelitian ini adalah metode kuantitatif. Pendekatan kuantitatif merupakan pendekatan yang menekankan pada fenomena yang dikaji secara kuantitatif sehingga mengkedepankan penggunaan angka-angka, pengolahan statistik, struktur dan percobaan terkontrol (Saunders, Lewis \& Thornhill, 2009).

\section{Pengukuran}

Komitmen organisasi menurut Allen \& Meyer (1990) menyatakan bahwa karyawan yang memiliki komitmen akan bekerja penuh dedikasi, yang membuat karyawan memiliki keinginan untuk memberikan tenaga dan tanggung jawab yang lebih untuk mendukung kesejahteraan dan keberhasilan organisasi melalui tiga komponen komitmen organisasi. Tiga komponen tersebut adalah komitmen afektif, komitmen kontinual dan komitmen normatif. Komitmen organisasi dalam penelitian ini akan diukur menggunakan Skala Komitmen Organisasi yang dikembangkn oleh Universitas Tarumanagara. Skala komitmen organisasi terdiri dari 18 item dimana 6 item termasuk ke dalam komitmen afektif, 6 item untuk komitmen kontinual dan 6 item mewakili komitmen normatif. Skala yang digunakan pada alat ukur ini adalah skala likert.

Variabel selanjutnya dalam penelitian ini adalah Engaging Leadership. Engaging Leadership merupakan gaya kepemimpinan yang menunjukkan penghargaan terhadap karyawan dan kepedulian terhadap perkembangan dan kesejahteraan mereka yang dilakukan dengan menginspirasi, menguatkan dan meningkatkan hubungan antar anggota tim (Schaufeli, 2015). Sejalan dengan teori yang digunakan, alat ukur engaging leadership dalam penelitian ini adalah Engaging Leadership Scale yang dikembangkan oleh Schaufeli (2015). Engaging Leadership Scale mengukur engaging Leadership menggunakan 12 item yang mengukur 4 aspek di dalamnya, yaitu memberdayakan, menginspirasi, menguatkan dan meningkatkan hubungan antar anggota tim. Skala yang digunakan pada alat ukur ini adalah skala likert. 
Sementara itu Proximal Withdrawal States (PWS) adalah perluasan dari kriteria turnover yang melihat dua antesenden utama dan terdekat dengan turnover, yaitu preferensi untuk keluar atau menetap dalam organisasi (leaving atau staying) dan perceived control over preference (enthusiastic atau reluctant) (Hom et al., 2012). PWS diukur menggunakan Proximal Withdrawal States Questioner yang dikembangkan oleh Hom et al. (2012). Alat ukur ini terdiri dari 2 bagian. Bagian pertama terdiri dari 1 item yang akan mengarahkan responden kepada salah satu dari 4 kondisi yang berbeda. Pada bagian kedua akan dimunculkan 5 sampai 6 item pernyataan pada masing-masing kondisi untuk melihat seberapa kuat seseorang berada pada kondisi tersebut. Skala yang digunakan adalah skala likert.

\section{Prosedur Penelitian}

Pelaksanaan penelitian diawali dengan pencarian alat ukur sesuai dengan teori yang digunakan pada penelitian. Kemudian dilanjutkan dengan menerjemahkan alat ukur berbahasa Inggris menjadi Bahasa Indonesia oleh penerjemah tersumpah. Setelah alat ukur siap, peneliti melakukan uji validitas konstruk dengan memberikan alat ukur kepada 4 orang untuk kemudian dipahami kembali setiap itemnya. Setelah mendapat feedback, peneliti melakukan beberapa penyesuaian sehingga alat ukur lebih mudah dimengerti oleh responden. Selanjutnya alat ukur dipindahkan ke dalam google form, untuk mempermudah responden dalam pengerjaan.

\section{HASIL DAN PEMBAHASAN}

Variabel bebas yang digunakan pada penelitian ini adalah engaging leadership. Sementara variabel terikat pada penelitian ini adalah komitmen organisasi yang terdiri dari 3 dimensi yaitu komitmen afektif, komitmen kontinual, dan komitmen normatif. Analisa dilakukan dengan menggunakan regresi linear sederhana.

Tabel 1. Uji regresi peran Engaging Leadership terhadap komitmen organisasi Sumber tabel: Hasil pengolahan data SPSS 22.0

\begin{tabular}{|c|c|c|c|c|c|c|c|}
\hline & \multirow{2}{*}{ Predictor } & \multirow[t]{2}{*}{ B } & \multirow[t]{2}{*}{$T$} & \multirow[t]{2}{*}{ Sig. } & \multicolumn{3}{|l|}{ Model } \\
\hline & & & & & $\mathbf{F}$ & $\mathbf{R}$ & $R^{2}$ \\
\hline \multirow[t]{2}{*}{$\begin{array}{l}\text { Komitmen } \\
\text { Organisasi }\end{array}$} & & & & & 59.511 & .410 & .168 \\
\hline & $\begin{array}{l}\text { Engaging } \\
\text { Leadership }\end{array}$ & .263 & 7.714 & .000 & & & \\
\hline
\end{tabular}

Uji regresi pertama yang dilakukan adalah uji regresi peran engaging leadership terhadap komitmen organisasi. Nilai signifikansi regresi pada perhitungan peran engaging leadership terhadap komitmen organisasi menunjukan hasil .000 yang berarti engaging leadership secara signifikan berperan terhadap komitmen organisasi. Berdasarkan tabel 1 juga diketahui bahwa perhitungan regresi atas variabel engaging leadership terhadap variabel komitmen organisasi adalah sebesar $\mathrm{R}^{2}=0.168$. Nilai tersebut berarti bahwa engaging leadersip dalam penelitian ini memiliki peran sebesar $16.8 \%$ terhadap komitmen organisasi.

Perhitungan selanjutnya adalah terkait peran engaging leadership terhadap komitmen organisasi dalam 4 situasi PWS. Berdasarkan uji regresi, variabel engaging leadership pada reluctant stayers, reluctant leavers dan enthusiastic stayers berperan signifikan terhadap komitmen organisasi. Hal tersebut berarti bahwa engaging leader dapat memprediksi komitmen organisasi pada karyawan PT. X. Sebaliknya, pada partisipan dalam situasi enthusiastic leavers, engaging leadership tidak dapat memprediksi komitmen organisasi partisipan. 
Tabel 2. Uji regresi peran Engaging Leadership terhadap komitmen organisasi dalam situasi Proximal Withdrawal States

Sumber tabel: Hasil pengolahan data SPSS 22.0

\begin{tabular}{llll}
\hline PWS & F & Sig. & R \\
\hline Enthusiastic Leavers & 1.183 & $.302^{\mathrm{b}}$ & .106 \\
Reluctant Stayers & 8.771 & .004 & .121 \\
Reluctant Leavers & 21.868 & .000 & .627 \\
Enthusiastic Stayers & 18.496 & .000 & .084 \\
\hline
\end{tabular}

Terdapat beberapa hal yang dapat di bahas dari hasil penelitian ini. Diawali dengan adanya pengaruh signifikan dari engaging leadership terhadap komitmen organisasi. Hasil penelitian ini sejalan dengan penelitian Schaufeli (2015) dimana terdapat hubungan engaging leadership dengan komitmen organisasi secara langsung. Tiga komponen komitmen yang dimiliki karyawan terhadap organisasi dapat dimunculkan melalui pengalaman bekerja yang positif (Meyer \& Allen, 1997). Pengalaman bekerja yang positif tersebut dapat diperoleh dengan terpenuhinya kebutuhan dasar karyawan (Van den Broeck et al., 2008). Schaufeli selanjutnya memberikan jawaban atas pemenuhan kebutuhan dasar karyawan melalui engaging leadership. Engaging leader memenuhi kebutuhan dasar karyawan dengan memberdayakan karyawan (Memberikan wewenang dan otoritas atas pekerjaan yang dilakukan), menginspirasi karyawan (meningkatkan antusias karyawan terhadap visi dan rencana dan membuat karyawan merasa terlibat dalam misi yang penting), menguatkan karyawan (memberikan karyawan kebebasan dan tanggung jawab dengan mendelegasikan tugas) dan menguatkan hubungan antar anggota tim (mendorong kolaborasi dan mempromosikan semangat tim yang tinggi) (Schaufeli, 2015). Hal ini menunjukan bagaimana engaging leadership mampu berperan pada komitmen organisasi, sehingga dapat dikatakan semakin tinggi engaging leadership yang dialami karyawan, semakin tinggi pula komitmen organisasi karyawan tersebut.

Perhitungan selanjutnya dilakukan pada situasi PWS, namun pada 4 situasi PWS, engaging leadership berperan signifikan hanya pada situasi reluctant stayers, reluctant leavers dan enthusiastic stayers. Engaging leadership berperan terhadap komitmen organisasi pada situasi reluctant stayers sebesar $12,1 \%$, pada reluctant leavers sebesar $62,7 \%$, pada enthusiastic stayers sebesar $8,4 \%$ dan tidak signifikan pada enthusiastic leavers. Hal inilah yang menyebabkan perlunya dilakukan pemetaan kedalam 4 situasi PWS tersebut, sehingga dapat dipahami lebih lagi bahwa tidak pada semua situasi engaging leadership dapat berpengaruh pada komitmen organisasi.

Peran engaging leadership terhadap komitmen organisasi pada situasi reluctant stayers terdapat sebesar $12,1 \%$. Hal ini kemudian menjadi pertanyaan bagaimana engaging leadership dapat meningkatkan komitmen organisasi karyawan. Peneliti kemudian melakukan perhitungan lebih mendalam untuk melihat peran engaging leadership terhadap dimensi komitmen organisasi yang meliputi komitmen afektif, kontinual dan normatif. Hasil menunjukan bahwa engaging leadership hanya signifikan terhadap dimensi kontinual dan normatif. Dimensi komitmen kontinual dilihat berdasarkan persepsi karyawan tentang kerugian yang akan dihadapinya jika meninggalkan organisasi, sedangkan Komitmen normatif dilihat melalui perasaan karyawan tentang kewajiban yang harus diberikan kepada organisasi (Allen \& Meyer, 1990). Hal ini cukup dapat dipahami, melihat karyawan pada situasi reluctant stayers sendiri merupakan 
karyawan yang memiliki preferensi untuk keluar namun tidak memiliki kontrol atas preferensi tersebut. Upaya yang dapat dilakukan PT.X adalah dengan meningkatkan engaging leadership sehingga komitmen organisasi karyawan dapat meningkat.

Hasil selanjutnya menunjukan bahwa peran engaging leadership terhadap komitmen organisasi cukup besar pada situasi reluctant leavers. Reluctant leavers adalah situasi dimana seseorang memiliki keinginan untuk bertahan di dalam perusahaan, namun tidak memiliki kontrol atas hal tersebut. Karyawan dengan reluctant leavers biasanya memiliki keterikatan yang tinggi dengan perusahaan, yang muncul akibat adanya pengalaman yang menyenangkan selama bekerja di perusahaan tersebut (Li et al., 2016). Perhitungan selanjutnya menghitung peran engaging leadership terhadap dimensi komitmen organisasi meliputi komitmen afektif, kontinual dan normatif pada situasi reluctant leavers. Hasil menunjukan bahwa engaging leadership signifikan berperan terhadap dimensi afektif dan normatif. Preferensi reluctant leavers untuk menetap, cukup menginformasikan bagaimana reluctant leavers memiliki pengalaman positif terhadap perusahaan ( $\mathrm{Li}$ et al., 2016). Hal ini menjawab pula bagaimana engaging leadership yang memenuhi kebutuhan dasar karyawan, dapat memberikan peran yang cukup tinggi bagi komitmen afektif dan normatif pada reluctant leavers.

Peran engaging leadership terhadap komitmen organisasi pada situasi enthusiastic stayers adalah sebesar 8,4\%. Dimana perhitungan selanjutnya menjelaskan bahwa engaging leadership berperan hanya terhadap dimensi afektif dan normatif. Karyawan pada enthusiastic stayers memiliki kepuasan, komitmen dan keterlibatan kerja yang tinggi pada organisasi (Li et al., 2016), hal ini cukup dapat menjelaskan bagaimana pemenuhan kebutuhan dasar karyawan melalui engaging leadership, dapat berperan langsung terhadap meningkatnya komitmen afektif dan normatif karyawan. Uji t test data demografi lama bekerja terhadap komitmen organisasi pada situasi enthusiastic staryers menunjukan adanya perbedaan yang signifikan antara lama bekerja. Semakin lama karyawan bekerja memiliki komitmen organisasi yang semakin tinggi. Dengan hal tersebut maka dapat dilihat bahwa waktu lamanya karyawan bekerja juga berperan bagi komitmen organisasi di situasi enthusiastic stayers. Usia responden pada situasi ini juga memiliki hubungan dengan komitmen organisasi.

Hasil perhitungan juga menunjukan bahwa engaging leadership tidak berperan terhadap komitmen organisasi pada situasi enthusiastic leavers. Li et al. (2016) menyatakan bahwa enthusiastic leavers memiliki kontrol yang tinggi akan keputusannya untuk meninggalkan organisasi. Karyawan dengan enthusiastic leavers dapat kapan saja meninggalkan organisasi bahkan tanpa tujuan yang pasti di luar organisasi. Hal ini dapat menjadi salah satu penyebab engaging leadership tidak memiliki peran terhadap komitmen karyawan yang berada pada situasi enthusiastic leavers. Perhitungan selanjutnya juga menunjukan bahwa engaging leadership tidak memiliki peran terhadap ketiga dimensi komitmen organisasi pada situasi enthusiastic leavers.

\section{KESIMPULAN DAN SARAN}

Penelitian ini dilakukan untuk melihat peran engaging leadership terhadap komitmen organisasi dalam situasi PWS. Berdasarkan perhitungan yang telah dilakukan diketahui bahwa terdapat pengaruh yang signifikan dari variabel engaging leadership terhadap komitmen organisasi sebesar 16,8 \%. Hal ini berarti bahwa dengan adanya engaging leadership yang baik maka komitmen organisasi individu akan meningkat. Sedangkan pada 4 situasi PWS, engaging leadership berperan signifikan pada situasi reluctant stayers, reluctant leavers dan enthusiastic stayers. Engaging leadership berperan terhadap komitmen organisasi pada situasi reluctant stayers sebesar 12,1\%, pada reluctant leavers sebesar $62,7 \%$ dan pada enthusiastic stayers 
sebesar 8,4\%. Hasil perhitungan juga menunjukan bahwa engaging leadership tidak berperan terhadap komitmen organisasi pada situasi enthusiastic leavers.

Selanjutnya secara lebih mendalam peneliti melakukan perhitungan peran engaging leadership terhadap 3 dimensi dalam komitmen organisasi, meliputi afektif, kontinual dan normatif pada 4 situasi PWS. Hasil perhitungan pada situasi enthusiastic leavers menunjukan bahwa, engaging leadership tidak memiliki peran terhadap komitmen afektif, kontinual dan normatif. Sedangkan hasil pada situasi reluctant stayers menunjukan bahwa terdapat peran signifikan dari engaging leadership terhadap komitmen kontinual dan normatif. Pada situasi reluctant leavers dan enthusiastic stayers, engaging leadership memiliki peran signifikan terhadap komitmen afektif dan normatif.

Melihat bahwa engaging leadership hanya berpengaruh sebesar 16,8\% terhadap komitmen organisasi, maka perlu dilakukan pengukuran pada variabel lain, seperti variabel kepuasan kerja atau keterlibatan kerja yang juga memiliki hubungan dengan komitmen organisasi. Secara signifikan engaging leadership juga memiliki peran terhadap komitmen organisasi dalam situasi reluctant stayers, reluctant leavers dan enthusiastic stayers, namun tidak memiliki peran terhadap komitmen organisasi dalam enthusiastic stayers. Dengan hasil tersebut, maka penelian selanjutnya perlu melihat variabel lain yang dapat berperan terhadap komitmen organisasi dalam situasi enthusiastic leavers. Hal tersebut bertujuan agar organisasi mampu mengantisipasi terjadinya turnover di masa depan. Dengan semakin kecil karyawan yang berada pada situasi enthusiastic leavers, maka semakin kecil pula peluang terjadinya turnover di masa depan dan tujuan penelitian dapat tercapai.

Berdasarkan hasil penelitian ini, kodisi PT.X saat ini cukup baik, karna dari 295 karyawan sebagai responden terdapat 202 responden atau 68,47\% karyawan yang berada pada situasi enthusiastic stayers. Hal ini menunjukan bahwa sebagian besar karyawan PT.X cukup memiliki pengalaman positif terhadap perusahaan. Namun diluar hal tersebut, PT.X tetap tidak bisa lengah. Hal ini dikarenakan terdapat sebanyak 66 karyawan $(22,37 \%)$ berada pada situasi reluctant stayers dan 12 karyawan pada situasi enthusiastic leavers (4,07\%). PT.X perlu melakukan pratinjau kembali, hal apa saja yang dapat ditingkatkan untuk menghindari peluang terjadinya turnover di masa depan. Beberapa hal yang dapat dilakukan PT.X diantaranya adalah meninjau kembali exit checklist yang telah diisi oleh karyawan yang keluar dalam beberapa waktu terakhir. Selanjutnya perusahaan dapat memindahkan fokus pengembangan kepemimpinan. Saat ini PT. X lebih berfokus pada produktivitas, sementara pada engaging leadership, fokus yang disarankan adalah pada pemenuhan kebutuhan karyawan. Diharapkan dengan terpenuhinya kebutuhan karyawan, maka karyawan akan memiliki komitmen yang lebih tinggi terhadap perusahaan.

\section{Ucapan Terima Kasih (Acknowledgement)}

Penulis mengucapkan terima kasih sebanyak-banyaknya pada PT. X yang sudah berperan dalam penelitian ini. Penelitian ini tidak dapat berjalan tanpa dukungan dari berbagai pihak, salah satunya adalah pihak yang melakukan review terhadap penelitian ini. Atas hal tersebut, penulis mengucapkan banyak terima kasih. 


\section{REFERENSI}

Allen, N.J., \& Meyer, J.P. (1990). A three-component conceptualization of organizational commitment. Human Resource Management, 1(1), 61-89. https://doi.org/10.1016/1053 4822(91)90011-Z

Hom, P. W., Mitchell, T. R., Lee, T. W., \& Griffeth, R. W. (2012). Reviewing employee turnover: Focusing on proximal withdrawal statesand an expanded criterion. Psychological Bulletin, 138, 831-858. doi:10.1037/a0027983

Kumar, R. (2005). Research methodology: Step by step guide for beginners (2 ${ }^{\text {nd }}$ ed.). London: SAGE Publications Ltd.

Li, J. J., Lee, T. W., Mitchell, T. R., Hom, P., \& Griffeth, R. W. (2016). The effects of proximal withdrawal states on job attitudes, job searching, intent to leave, and employee turnover. Journal of Applied Psychology, 101(10), 1436-1456. https://doi.org/10.1037/apl0000147

Meyer, J. P., \& Allen, N. J. (1997). Advanced topics in organization behavior series. Commitment in the workplace: Theory, research, and application. New York, NY: Sage Publications, Inc.

Neuman, W. L. (2014). Social research methods qualitative and quantitative approach (7th ed.). England: Pearson Education Limited.

Pekasa, E., \& Rostiana. (2018). Job embeddedness terhadap kinerja dengan keterikatan kerja dan keinginan untuk menetap sebagai mediator. Jurnal Muara Ilmu Sosial, Humaniora, dan Seni, 2(1). 335-341. https://journal.untar.ac.id/index.php/jmishumsen/article/view/1635

Rahmadani, V. G., Schaufeli, W. B., Ivanova, T. Y., \& Osin, E. N. (2019). Basic psychological need satisfaction mediates the relationship between engaging leadership and work engagement: A cross-national study. Human Resource Development Quarterly, 1-19. https://doi.org/10.1002/hrdq.21366

Schaufeli, W. B. (2015). Engaging leadership in the job demands-resources model. Career Development International, 20(5), 446-463. doi: 10.1108/cdi-02-2015-0025

Thornhill, A., Saunders, M., \& Lewis, P. (2009). Research methods for business students. Essex: Pearson Education Ltd.

Van den Broeck, A., Vansteenkiste, M., De Witte, H., \& Lens, W. (2008). The role of basic need satisfaction in explaining the relationships between job demands, job resources, burnout and engagement. Work and Stress, 22(3), 277-294. https://doi.org/10.1080/02678370802393672 